\title{
Phylogenetic Relationships Among Species of Phillipsia Inferred from Molecular and Morphological Data
}

\section{Citation}

Hansen, Karen, Donald H. Pfister, and David S. Hibbett. 1999. Phylogenetic relationships among species of Phillipsia inferred from molecular and morphological data. Mycologia 91(2): 299-314.

\section{Published Version}

http://dx.doi.org/10.2307/3761375

\section{Permanent link}

http://nrs.harvard.edu/urn-3:HUL.InstRepos:3153299

\section{Terms of Use}

This article was downloaded from Harvard University's DASH repository, and is made available under the terms and conditions applicable to Other Posted Material, as set forth at http:// nrs.harvard.edu/urn-3:HUL.InstRepos:dash.current.terms-of-use\#LAA

\section{Share Your Story}

The Harvard community has made this article openly available.

Please share how this access benefits you. Submit a story.

Accessibility 


\section{Mycological Society of America}

Phylogenetic Relationships among Species of Phillipsia Inferred from Molecular and Morphological Data

Author(s): Karen Hansen, Donald H. Pfister, David S. Hibbett

Source: Mycologia, Vol. 91, No. 2 (Mar. - Apr., 1999), pp. 299-314

Published by: Mycological Society of America

Stable URL: http://www.jstor.org/stable/3761375

Accessed: 05/06/2009 21:08

Your use of the JSTOR archive indicates your acceptance of JSTOR's Terms and Conditions of Use, available at http://www.jstor.org/page/info/about/policies/terms.jsp. JSTOR's Terms and Conditions of Use provides, in part, that unless you have obtained prior permission, you may not download an entire issue of a journal or multiple copies of articles, and you may use content in the JSTOR archive only for your personal, non-commercial use.

Please contact the publisher regarding any further use of this work. Publisher contact information may be obtained at http://www.jstor.org/action/showPublisher?publisherCode=mysa.

Each copy of any part of a JSTOR transmission must contain the same copyright notice that appears on the screen or printed page of such transmission.

JSTOR is a not-for-profit organization founded in 1995 to build trusted digital archives for scholarship. We work with the scholarly community to preserve their work and the materials they rely upon, and to build a common research platform that promotes the discovery and use of these resources. For more information about JSTOR, please contact support@ jstor.org. 


\section{Phylogenetic relationships among species of Phillipsia inferred from molecular and morphological data}

\author{
Karen Hansen ${ }^{1}$ \\ Donald H. Pfister \\ David S. Hibbett \\ Harvard University Herbaria, Cambridge, \\ Massachusetts 02138
}

\begin{abstract}
The internal transcribed spacers (ITS) of the nuclear ribosomal DNA have been sequenced from 29 collections of Phillipsia, mainly from the New World. The $P$. domingensis complex, collections with a range of colors but otherwise referable to $P$. domingensis s.l. based on spore ornamentation, were studied. Three distinctive species of Phillipsia also were included. The sequences were analysed to infer phylogenetic relationships within Phillipsia, using parsimony. Morphological features were studied separately, and then evaluated in the context of the ITS phylogeny. Four distinct rDNA lineages, supported by ascospore ornamentation, were identified: the $P$. crispata, the $P$. domingensis, the $P$. olivacea and the $P$. carnicolor lineages. SEM photographs of the ascospores are presented. Phillipsia lutea and another yellow form were nested within the $P$. domingensis complex, of those with reddish hymenial colors. Color has been emphasized in taxonomy of Phillipsia, but these results suggest that individuals with strikingly different coloration may be closely related. Levels of ITS sequence divergence in the $P$. domingensis lineage were low. Based on these data, and morphology as studied thus far, there is no justification for recognizing segregate species within the $P$. domingensis complex. The Old World collections of the $P$. domingensis complex were nested within the New World collections, which implies that the $P$. domingensis lineage is geographically widespread. Phillipsia rugospora is placed in synonymy with $P$. olivacea and a detailed description of this taxon is given. A lectotype is designated for $P$. olivacea.
\end{abstract}

Key Words: ITS, Pezizales, Sarcoscyphaceae, SEM, spore ornamentation

Accepted for publication November 9, 1998.

${ }^{1}$ Current address: Department of Mycology, University of Copenhagen, Øster Farimagsgade 2 D, DK-1353 Copenhagen K, Denmark. E-mail: karenh@bot.ku.dk

\section{INTRODUCTION}

Phillipsia Berk. is one of the more conspicuous genera within the Sarcoscyphaceae (Pezizales, Ascomycota). The species produce large, fleshy, brightly colored apothecia on decaying angiosperm wood and are presumed saprobes. Phillipsia is distinguished from other members of the family by asci with an internal eccentric thickened apical pad, by ellipsoid, inequilateral in profile view or symmetrical, successively maturing ascospores, which are smooth, wrinkled or ornamented with cyanophobic, parallel, longitudinal ridges, and by a rather poorly differentiated, thin outer excipulum of dense textura intricata or textura prismatica, arranged with the long axes of the cells parallel to the exterior. Although none of these characters are confined to Phillipsia this combination of characters is unique. The cyanophobic ridges have been shown [in $P$. domingensis (Berk.) Berk. and Wynnea americana Thaxter] to originate from the primary wall; no secondary wall material forms ( $\mathrm{Li}$ and Kimbrough 1996). This feature has only been demonstrated in the Sarcoscyphaceae and distinguishes the family from others of the Pezizales. Phillipsia is restricted to the subtropical and tropical regions of both the Old and New World. The genus has been reviewed by several authors (Boedijn 1933, Denison 1969, Le Gal 1953, Moravec 1997, Rifai 1968, Romero and Gamundi 1986), but no world-wide treatment of Phillipsia has been undertaken. While the generic delimitation has not been controversial (but see Moravec 1997 and Rifai 1968), there is confusion as to species limits. Many species have been collected only rarely (many are represented by a single apotheci$\mathrm{um})$, and many descriptions are vague. Thirtyone specific epithets have been used in Phillipsia at one time or another. However, the number of species recognized in taxonomic treatments varies, mainly due to difficulties that center on species delimitation in what we refer to here as the Phillipsia domingensis complex.

Taxonomic history of Phillipsia.-The genus was introduced by Berkeley (1881) for seven species, allied by their firm flesh and somewhat corky consistency. It is unclear what Berkeley judged as being the distinctive features of the genus which he described as "Contextus lentus, cupulæ amplæ disciformes marginatæ, 
hymenium semper apertum." Massee (1896) redescribed two of Berkeley's type specimens and emended the generic description. However, he still included species now referred to Cookeina Kuntze and Sarcoscypha (Fries) Boudier. Not until the publications by Seaver (1928) and Boedijn (1933) did Phillipsia get its modern circumscription. Phillipsia domingensis, the most commonly identified taxon in Phillipsia, was designated as the type species (Seaver 1927). The name Phillipsia is conserved against the earlier homonym, Phillipsia C. Presl, which is a fossil (ICBN, App. IIIA).

Boedijn (1933) treated species from Indonesia, and suggested that there were but two species in the genus, $P$. domingensis and $P$. dochmia (Berk. \& M. A. Curtis) Seaver, and indicated that other described species were likely synonyms of $P$. domingensis. Seaver (1928) similarly placed several names in synonymy with $P$. domingensis. Several of their synonyms have subsequently been used to recognize independent taxa. Seaver described two new species from the Caribbean, $P$. gigantea Seaver (1925) and $P$. chardoniana Seaver (1928). Later Boedijn (1940) transferred one species, Humaria umbilicata Penz. \& Sacc. to Phillipsia. Le Gal (1953) provided the first and most useful synopsis of the genus. She recognized 13 species, largely by narrowing the broad concept of $P$. domingensis, based on studies of the type material. Full descriptions were given only for the five taxa from Madagascar, including one new species, $P$. carnicolor Le Gal. Denison (1969) accepted many of the taxa segregated by Le Gal. He treated ten species from Central America and the Caribbean (including six of those recognized by Le Gal). Five of these species he reported and described from Central America, two of which were new, $P$. lutea Denison and $P$. costaricensis Denison. Rifai (1968) treated the Australasian taxa, including four species, two of which were new combinations in the genus, $P$. hartmanii (Phill.) Rifai and P. minor (Wakef.) Rifai. At the same time he segregated the genus Aurophora Rifai, with $P$. dochmia as type, on the basis of its fan-shaped apothecia and gelatinous tissue of the medullary excipulum. Though he did not make the combinations he stated that $P$. inaequalis (Berk. \& M. A. Curtis) Berk. and P. hirneoloides (Berk.) Berk. were closely related. Paden (1974, 1977) described two new species from Central America, $P$. rugospora Paden and $P$. guatemalensis Paden, and gave detailed information on spore germination and conidial formation.

The Phillipsia domingensis complex.-The P. domingensis complex, as we have defined it here, is characterised by ellipsoid, inequilateral ascospores with $3-6(-7)$, prominent, longitudinal ridges, seen in pro- file view (visible in light microscopy $(\mathrm{LM}) \times 400$ ), medium to large apothecia, and with various hymenial colors: yellow, orange, red, purple to pink. The number of species recognized within the complex has depended on the relative weight placed on macroscopic characters, such as size, shape, orientation and color of the apothecia, and thickness of the excipular tissues. Microscopically, the number of ridges on the spore surfaces, has been used as a distinctive character. As we will show, these characters do not necessarily delimit monophyletic groups. Some examples of ambiguities and difficulties in interpreting this group follow in a brief review of some of the species that have been recognized in the $P$. domingensis complex.

Phillipsia chardoniana was distinguished by its thin flesh and brick-reddish hymenium (Seaver 1925) and $P$. gigantea on the basis of its thick flesh and large apothecia (Seaver 1928). These two species have not been subsequently collected or recognized and when treated (Boedijn 1933, Denison 1969) they have been synonymized with $P$. domingensis. Phillipsia subpurpurea Berk. \& Broome differs only critically from $P$. domingensis, by slightly larger apothecia and ascospores with 4-6 (7) ridges as opposed to 3-6 ridges in $P$. domingensis. It was accepted by Le Gal (1953) and Rifai (1968). Phillipsia carminea (Pat.) Le Gal was stated to differ from $P$. domingensis in being stipitate, villose on the outside, and by having slightly finer ridges on the ascospores (Le Gal 1959). Phillipsia ineaqualis was distinguished by its orange, rather than red hymenium (Le Gal 1953). Two other questionable species, with the same type of spore ornamentation (4-6 longitudinal ridges), are $P$. dochmia and $P$. hirneoloides, separated by their fan-shaped apothecia, with respectively yellow to yellowish brown, and red hymenia (both sensu Le Gal 1953). According to Rifai (1968), P. carminea, P. ineaqualis, P. doch$m i a$, and $P$. hirneoloides might belong in the genus Aurophora, based on the presence of a gelatinous matrix in the medullary excipulum (see Taxonomic history of Phillipsia). Paden (1977), in his description of $P$. guatemalensis, noted that it differs from P. domingensis in the color of the hymenium ("rosaceous tan"), its smaller apothecia (up to $3 \mathrm{~cm}$ ) with thin, rather brittle flesh and by somewhat shorter ascospores $(21-25 \times 12-13 \mu \mathrm{m})$. Phillipsia guatemalensis has been reported only from the type locality (a single collection from Guatemala). Phillipsia lutea was distinguished on the basis of its 4-spored asci, large ascospores and its yellow hymenium, but with the spore-shape and ornamentation as in the $P$. domingensis complex (Denison 1969).

Moravec (1997), found considerable variability in thickness and number of ridges on individual asco- 
spores which were taken from the same apothecia of collections of $P$. domingensis from Madagascar. He concluded that there are no important features that separate these into further species. Moravec's three collections of $P$. domingensis showed variability in hymenial colors "from pink-red to light pink-violaceous or red- to orange-violaceous."

The goal of the present study was to provide insight into phylogenetic relationships among species of Phillipsia and to facilitate species delimitation using rDNA sequence data. We focused particularly on the $P$. domingensis complex, which has been classified as few or many species based on morphological criteria. We studied specimens that could be referred to $P$. domingensis s.l. Distinctive species of Phillipsia were included to test the monophyly of the $P$. domingensis complex, and to evaluate morphological characters previously used in the delimitation of the species.

\section{MATERIALS AND METHODS}

Material studied.-All collections of Phillipsia in FH and selected collections from AAU, BPI, C, CFMR, CSU, MBM, NO, NY, OSC and UVIC (Holmgren et al 1990) were examined morphologically. Representative collections, and the material included in the molecular part of the study, are listed in the results section under morphotaxonomy. DNA sequences from the internal transcribed spacers (ITS) of nuclear ribosomal DNA were obtained from 24 of the herbarium collections, from Central and South America, including 17 collections from the $P$. domingensis complex [of which 15 were referred to $P$. domingensis s.l., one to $P$. lutea and one to another yellow form, "P. yellow" (1) (Numbers in parentheses refer to collection codes in TABLE I)], five collections of $P$. olivacea Rick, and two collections of $P$. crispata (Berk. \& M. A. Curtis) Le Gal. Additionally, sequences were obtained from three isolates from Thailand, including one isolate each of $P$. domingensis s.l., "P. yellow" (2), and P. carnicolor (TABLE I). The material used for molecular studies were collected from 1981 to 1997 . The excipulum structure, a thick medullary excipulum of loose textura intricata, and the large size of the apothecia, generally makes specimens of Phillipsia easy to preserve. However, often only a few apothecia are produced at a time, thus making collections rather small. Furthermore, mycelia of more than one species may be fruiting on the same branch, e.g., $P$. crispata (2) and P. olivacea (3) (TABLE I), and therefore there is the risk of mixing collections. DNA ITS sequence-data for $P$. domingensis s.l. coll. nr. DHP PR40 and A. de Meijer-2605, and Nanoscypha tetraspora (Seaver) Denison, were kindly provided by F. A. Harrington (unpubl data).

Nanoscypha tetraspora was used for rooting purposes. This choice is based on a higher-level phylogenetic analysis by Harrington et al (1999), which suggests that Nanoscypha is the sister group to Phillipsia. However, the Phillipsia-Na- noscypha clade was supported by only $61 \%$ of the bootstrap replicates (Harrington et al 1999).

Morphological techniques.-The material was studied by LM, and identified to morphological species. Pieces of apothecia were revived in water for a minimum of $3 \mathrm{~h}$. Vertical, median sections $25 \mu \mathrm{m}$ thick were cut on a freezing microtome stage (Physitemp Inst. Inc. Saddle Brook, New Jersey). Hymenial elements were studied by teasing apart individual asci and paraphyses with a fine needle. Measurements and descriptions of microscopic characters were made on material mounted in water, unless otherwise stated. Other chemicals used were cotton blue in lactic acid, congo red in ammonia and Melzer's reagent. Sections were further mounted in black India ink to determine absence or presence of gel in the excipulum. The India ink fills the spaces between hyphae when gelatinous material is absent. The spore surface from representative specimens of $P$. domingensis s.l. (T. Læssøe AAU-44800; T. Læssøe AAU-44913; DHP-7169), P. lutea (NY-4113), P. crispata (T. Læssøe AAU44895a), P. olivacea (T. Læssøe AAU-44895b; T. Læssøe AAU-43162), P. carnicolor (DHP-7126) and Nanoscypha tetraspora (DHP PR-61), were viewed by an AMRay 1000 scanning electron microscope (SEM). Ascospores were collected in a water droplet placed on the hymenium and immediately pipetted onto a cover glass, dried, placed on a stub and coated with gold-palladium alloy. For a few specimens the ascospores were viewed directly on the surface of the hymenium, likewise placed on a stub and coated with goldpalladium alloy. Microanatomical terminology follows Korf (1973) with tissue types described from vertical, median sections of apothecia. Color-codes refer to Kornerup and Wanscher (1974).

Culturing and molecular methods.-DNA was isolated from specimens air dried with or without heat, and from cultures. A small piece (ca $2 \mathrm{~mm}$ ) of an apothecium was cleaned under a dissecting microscope and ground in liquid nitrogen. Cultures were obtained from ascospores from fresh apothecia which were suspended over agar plates. Cultures for DNA isolation (the three Thailand isolates) were grown on MEYE agar $(0.3 \%$ malt extract, $0.3 \%$ yeast extract, $1 \%$ glucose, $0.5 \%$ peptone agar), at room temperature under ambient light for $3 \mathrm{wk}$ and harvested by scraping off the surface mycelium. The samples were extracted in $500 \mu \mathrm{L}$ $0.15 \mathrm{M} \mathrm{NaCl}, 50 \mathrm{mM}$ Tris (pH8.0), $50 \mathrm{mM}$ EDTA, 1\% SDS and placed in an approximately $70 \mathrm{C}$ heat block for 10-30 min, with occasional mixing. The suspension was extracted twice with an equal volume of phenol-chloroform-isoamyl alcohol (PCI 24:24:1), and once with chloroform-isoamyl alcohol (CI 24:1). DNA was purified with GeneClean (Bio 101, La Jolla, California). A range of dilutions from the DNA-extract was made in water $(1: 10,1: 100,1: 1000)$ and used for polymerase chain reaction (PCR) amplification. The internal transcribed spacers (ITS1 and ITS2) and the $5.8 \mathrm{~S}$ of nuclear ribosomal DNA were symmetrically amplified, using primers ITS4 and ITS5 (White et al 1990). PCR products were purified with QIAquick Spin Columns (1996 QIAGEN). In addition to the primers used for PCR, primers ITS1, ITS3 and 5.8S (Hibbett et al 1995, White et al 1990) were used in dye-terminator cycle sequencing (Applied 
TABLE I. Collections used in molecular phylogenetic study

\begin{tabular}{|c|c|c|}
\hline Morphological species & Geographic origin and voucher ${ }^{\mathrm{a}}$ & GenBank \\
\hline Nanoscypha tetraspora & Puerto Rico. DHP PR-61 (FH) & AF117352 \\
\hline Phillipsia carnicolor & Thailand. DHP-7126 (FH) & AF117353 \\
\hline P. crispata (1) & Ecuador. T. Læssøe AAU-44801 (AAU, C) & AF117354 \\
\hline$P$. crispata $(2)$ & Ecuador. T. Læssøe AAU-44895a (AAU, C) & AF117355 \\
\hline P. domingensis (1) & Puerto Rico. PR-1582 (FH) & AF117356 \\
\hline P. domingensis (2) & Puerto Rico. PR-1579 (CFMR) & AF 117357 \\
\hline P. domingensis (3) & Costa Rica. Franco-M 1270 (NY) & AF117358 \\
\hline P. domingensis (4) & Ecuador. T. Læssøe AAU-44913 (AAU, C) & AF117359 \\
\hline P. domingensis (5) & Ecuador. T. Læssøe AAU-44800 (AAU, G) & AF117360 \\
\hline P. domingensis $(6)$ & Costa Rica. CO-2032 (NO) & AF117361 \\
\hline P. domingensis $(7)$ & Costa Rica. CO-1975 (NO) & AF117362 \\
\hline P. domingensis (8) & USA. CO-1864 (NO) & AF117363 \\
\hline P. domingensis $(9)$ & USA. CO-10 Sept. 1985 (NO) & AF117364 \\
\hline P. domingensis $(10)$ & Puerto Rico. PR-1583 (FH) & AF117365 \\
\hline P. domingensis (11) & Brazil. A. de Meijer-1915 (FH, MBM) & AF117366 \\
\hline P. domingensis (12) & Ecuador. T. Læssøe AAU-43662 (AAU, C) & AF 117367 \\
\hline P. domingensis (13) & Ecuador. T. Læssøe AAU-44714 (AAU, C) & AF117368 \\
\hline P. domingensis (14) & Dominican Republic. DR-161 (CFMR) & AF117369 \\
\hline P. domingensis (15) & Dominican Republic. DR-321 (CFMR) & AF 117370 \\
\hline P. domingensis (16) & Brazil. A. de Meijer-2605 (FH, MBM) & AF 117371 \\
\hline P. domingensis (17) & Puerto Rico. DHP PR-40 (FH) & AF117372 \\
\hline P. domingensis (18) & Thailand. DHP-7169 (FH) & AF 117373 \\
\hline P. lutea & French Guiana. NY-4113 (NY) & AF117374 \\
\hline P. olivacea (1) & Costa Rica. Franco-M 1360 (NY) & AF 117375 \\
\hline P. olivacea (2) & Venezuela. Halling-5456 (NY) & AF117376 \\
\hline P. olivacea (3) & Ecuador. T. Læssøe AAU-44895b (AAU, C) & AF 117377 \\
\hline P. olivacea (4) & Ecuador. T. Læssøe AAU-43162 (C) & AF 117378 \\
\hline P. olivacea (5) & Ecuador. T. Læssøe AAU-43774 (AAU, C) & AF117379 \\
\hline "P. yellow" (1) & Costa Rica. CO-2168 (CFMR) & AF117380 \\
\hline "P. yellow" (2) & Thailand. DHP-7197 (FH) & AF117381 \\
\hline
\end{tabular}

a The culture numbers used for the Thailand material are identical with the collection numbers.

Biosystems, Foster City, California), following the manufacturer's protocol except that reaction volumes were $5 \mu \mathrm{L}$. Sequencing reactions were purified using ethanol precipitation. Sequencing reactions were electrophoresed and data collected on an Applied Biosystems 377 automated DNA sequencer. Preliminary phylogenetic analysis showed our single collections of $P$. lutea and " $P$. yellow" (1) to be nested within the $P$. domingensis complex. Since no other collections of these species were available for molecular studies, these samples were PCR-amplified and sequenced twice $(P$. lutea from a new extraction of DNA), to verify the sequences. The inclusion of the Thailand collection, " $P$. yellow" (2), later confirmed the placement of the yellow forms within the complex.

Analytical methods.-Sequences were edited and assembled using Sequencher 3.0 (GeneCodes, Ann Arbor, Michigan). Sequences have been deposited in GenBank (TABLE I). Complete sequences of ITS1-5.8S-ITS2 rDNA were manually aligned in the data editor of PAUP* $4.0 \mathrm{~d} 63$ (kindly provided by David Swofford, Smithsonian Institution, Washington, DC). Alignment gaps were inserted to maximize aligned sites. We inferred the approximate end points of the $18 \mathrm{~S}$, $5.8 \mathrm{~S}$ and $25 \mathrm{~S}$ rDNAs by alignment to homologous rDNA sequences and secondary structures from Saccharomyces (Georgiev et al 1981, Rubtsov et al 1980, Thweatt and Lee 1990, Yeh and Lee 1990). The data matrix is available from TreeBASE (http://phylogeny.harvard.edu/treebase) (S353).

Alignment gaps, representing putative insertion-deletion sites, were treated as missing data (gap $=$ missing coding). In a preliminary analysis, which did not include the Thailand collections, gaps were scored as characters (indel coding) following guidelines outlined in Hibbett et al (1995). The number of informative characters was increased under indel coding from 126 characters to 145 . The strict consensus trees obtained under the two coding schemes were identical and indel coding was therefore not further explored. Instead, analyses were performed with gapped positions included (with gap $=$ missing coding) or excluded. The goal of this exercise was to explore the sensitivity of the results to the inclusion of gapped positions, where there might be alignment ambiguities.

Phylogenetic analyses were performed in PAUP* 4.0d63. All characters were weighted equally and unordered. Due to the size of the data set, we were limited to heuristic searches, which are not guaranteed to find all shortest trees (Maddison 1991, Swofford 1993). We followed a search pro- 
tocol based on strategies designed by Maddison et al (1992) and Olmstead et al (1993). First, 100 heuristic searches were performed using TBR-branch swapping on an initial set of trees generated by random taxon addition sequences, with MAXTREES unrestricted, keeping up to two trees per replicate. Second, all most parsimonious trees from part 1 were used as starting trees for-complete TBR branch swapping, with MAXTREES set to 15000 . This method explores tree space from many starting points, which increases the probability of finding the shortest tree(s). Relative robustness of clades was assessed by the bootstrap (Felsenstein 1985), using 1000 heuristic searches, with simple taxon addition sequences, TBR branch swapping and MAXTREES set at 100 .

\section{RESULTS}

Morphotaxonomy.-A summary of the morphological characters observed in the specimens used in the molecular phylogenetic study is provided in TABLE II. The outer excipulum of the apothecia has been described variously. Rifai (1968) described it as "... prosenchymatous, hyphae delicate, either compactly interwoven or running parallel with the surface . . ,", whereas Denison (1969) described it as “... textura intricata to textura epidermoidea with the long axes of the cells parallel to the exterior ...," and Paden (1977) described it as textura epidermoidea. Finally, Moravec (1997) described the structure of the apothecia as "textura intricata to subepidermoidea ...." We recognize the outer excipulum to be composed of dense textura intricata to textura prismatica, with the long axes of the cells running parallel to the exterior, often with free hyphal tips protruding on the outer surface. In this case the use of tissue-type terms tends to obscure the basic understanding of the common structure of the excipulum.

Gel tissue in the apothecia were reported in the fieldnotes with several of the collections, but the spaces between the excipulum cells stained fully black in india ink. Thus, we found no evidence of gelatinous tissue. To further explore the possibility of presence of gelatinous tissue in Phillipsia, isotype material of $P$. hirneoloides and $P$. ineaqualis (FH-Herb. Curtis) were examined. We were unable to confirm the presence of gelatinous tissue and it is most likely that these taxa fall within the $P$. domingensis complex. However, material of these taxa were not available for molecular study.

Phillipsia carnicolor Le Gal, Prodr. Flore Mycol. Madagascar 4:281. 1953.

Phillipsia carnicolor is distinguished by the small, up to ca $1 \mathrm{~cm}$ diam, apothecia, short asci, 170-200 $\mu \mathrm{m}$ (Le Gal: 175-280 $\mu \mathrm{m}$ ), with a broad base, and small, 18.8-20.5-22.4 × 10.4-10.9-12.8 $\mu \mathrm{m}$ (Le Gal:
17-20 $\times$ 9.5-11 $\mu \mathrm{m})$, ellipsoid, slightly inequilateral ascospores, which are smooth or with very fine striations in LM (barely visible $\times 1000$ ), in SEM with an ornamentation of $6-8$, ca $0.3 \mu \mathrm{m}$ high, ca $0.7-1.3 \mu \mathrm{m}$ broad, longitudinal irregular, some anastomosing ridges (FIG. 1) (a few smooth ascospores were seen in SEM). See Le Gal $(1953,1959)$ for descriptions and drawings of $P$. carnicolor.

Commentary. Rifai (1968) and Denison (1969) tentatively list $P$. carnicolor in synonymy with $P$. hartman$i$, although Rifai states that the type specimen of $P$. hartmanii is not fully mature. For this reason the name $P$. carnicolor is used here. Moravec (1997) has likewise examined the type of $P$. hartmanii, and describes the ascospores as smooth in LM, but with a "fine irregular or even subreticulate ornamentation consisting of 'amoeboid' and irregularly arranged wrinkles (without a regular longitudinal striation)" in SEM (photos not shown by Moravec). Romero and Gamundi (1986) used the name $P$. hartmanii for a species with a much finer spore ornamentation (1318 ridges in profile view in SEM) than our collection. To settle the status of these two names additional collections from the type localities in Australia and Madagascar are needed. Phillipsia crenulata Berk. \& Br. is another species with small, up to $12 \mathrm{~mm}$ diam, apothecia, short asci and ascospores in the same size range $(16.5-23.5 \times 9-13)$, with 6-7 fine striae (Le Gal 1953). It is, as the name indicates, described with a crenate margin, whereas the Thailand collection has a smooth margin. The importance of this character is questionable, however, and this name remains problematic. Critical review of these Phillipsia species with small apothecia is needed.

Material. THAILAND. KANCHANABURI: Sai Yok National Park, 20.VII.97, D. H. Pfister (DHP-7246) (FH); Khao Yai National Park-Heo Narok, 10.VII.97, D. H. Pfister (DHP-7126) (FH) (DNA).

Phillipsia crispata (Berk. \& M. A. Curtis) Le Gal, Prodr. Flore Mycol. Madagascar 4:263, 1953.

The spore measurements, 22.4-24.8 $\times$ 10.4-13.6 $\mu \mathrm{m}$ (Le Gal: $22-33 \times 11-15 \mu \mathrm{m}$ ), and ornamentation of very fine, low, longitudinal, parallel ridges (barely visible in LM $\times 1000$ ), in SEM with 15-18, ca $0.3 \mu \mathrm{m}$ high, ca. $0.3 \mu \mathrm{m}$ broad, ridges in profile view (FIG. 2) and asci, 360-400 $\mu \mathrm{m}$ long, with a long tapering base, are diagnostic features of $P$. crispata. Our observations are in agreement with Le Gal (1953) and Denison (1969).

Material. BRAZIL. RIO GRANDE DO SUL: São Leopoldo, 1931, J. Rick (s.n.) (FH); RIO GRANDE DO SUL: Serro Azul, 1928, J. Rick (434 and two additional coll. s.n.) (FH). ECUADOR. NAPO: Añangu, Rio Napo Tropical rain forest, 20.VI.1983, T. Læssøe (T. Læssøe AAU-44801) (AAU, C) 


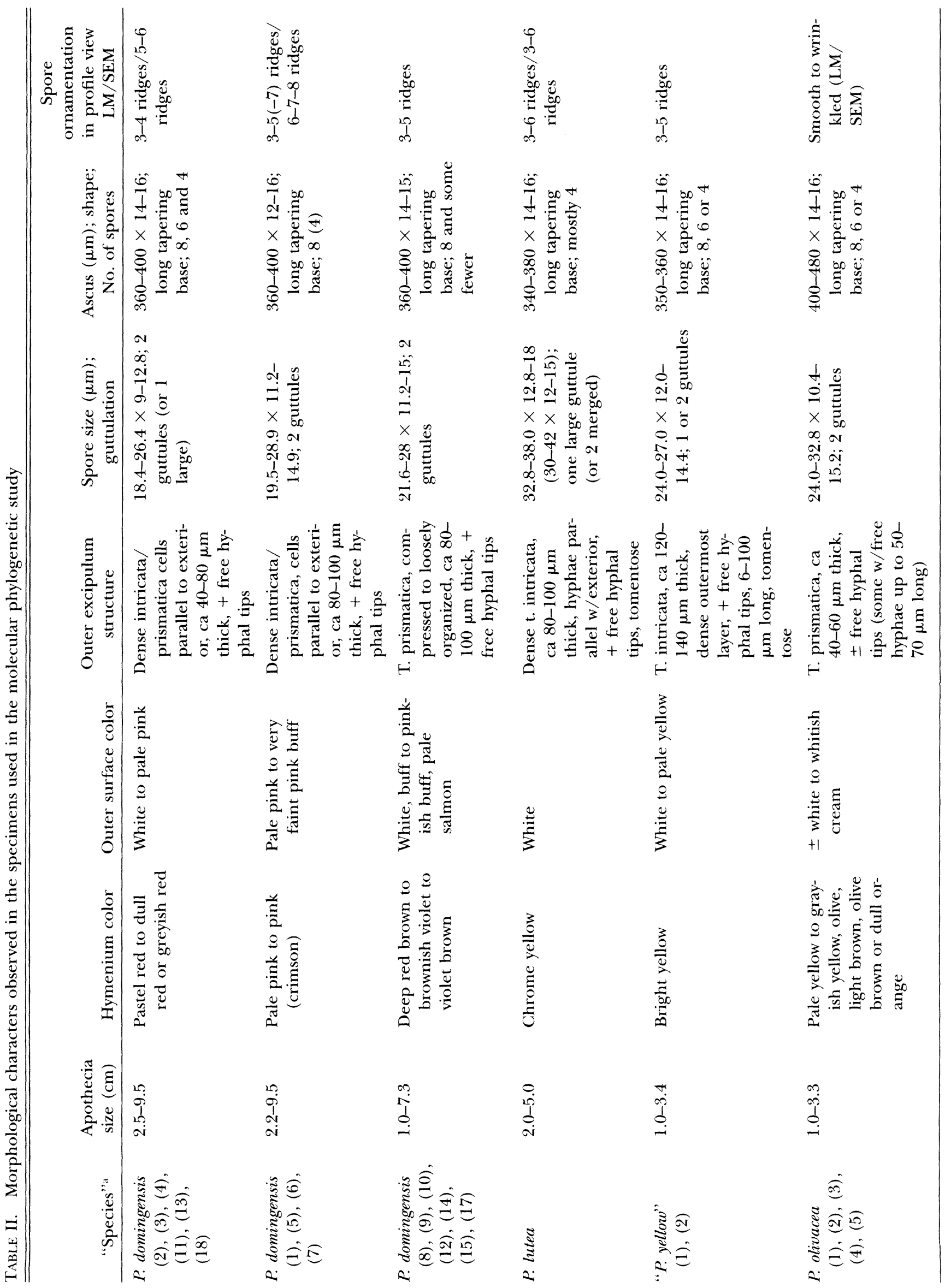




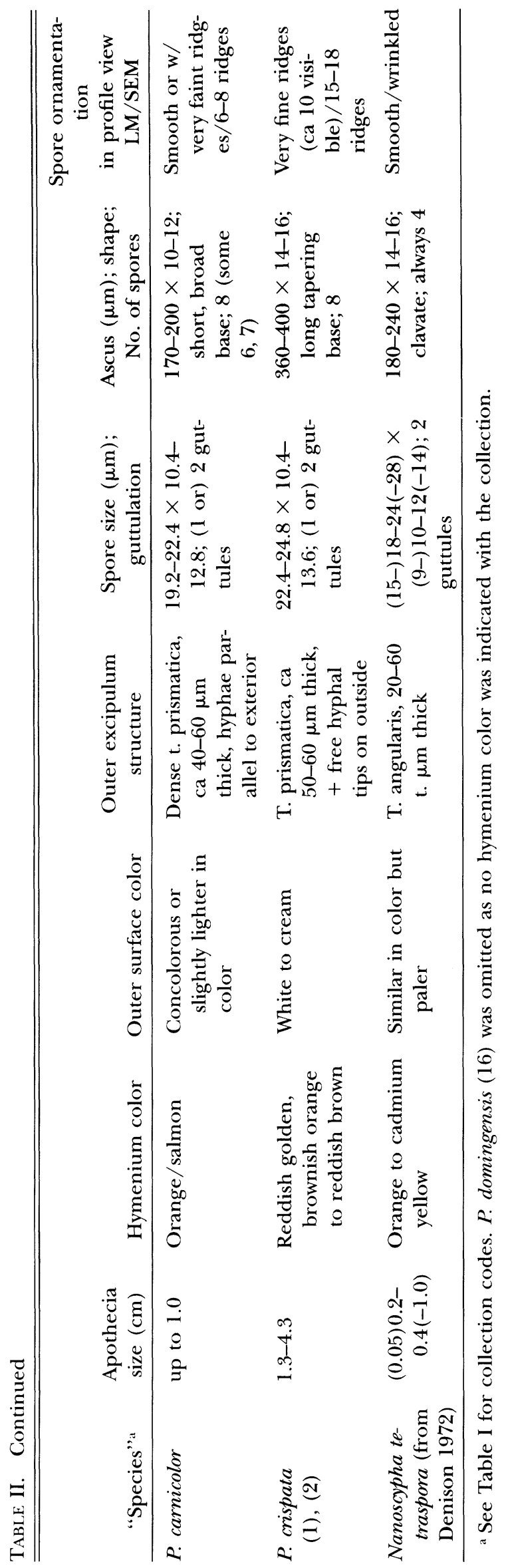

(DNA); ibid., 5.VII.1983, T. Læssøe (T. Læssøe AAU44895a) (AAU, C) (DNA).

The $P$. domingensis complex equals $P$. domingensis, $P$. lutea and other yellow Phillipsia's.

Phillipsia domingensis (Berk.) Berk., J. Linn. Soc. London Bot. 18:388. 1881.

Phillipsia domingensis is here characterized by its medium to large, $1.0-9.5 \mathrm{~cm}$ diam, apothecia, with the hymenium colors ranging from pink, pastel red to dull red, deep red-brown to violet-purplish brown, in combination with overlapping spore measurements within the range 18-29 $\times 9-15 \mu \mathrm{m}$, and with an spore ornamentation of 3-7 coarse, high, ridges in profile view (seen in $\mathrm{LM} \times 400$, mostly as light and dark bands), in SEM, ca $1.3 \mu \mathrm{m}$ high, ca. 1.3-2.0 $\mu \mathrm{m}$ broad ridges (FIGS. 3, 4).

Commentary. Collections included in the phylogenetic analysis were separated by hymenial colors (into three hymenial color categories, TABLE II). So far, however, we have not been able to find any consistent morphological characters correlated with color variation. This is in agreement with recent observations by Moravec (1997), who reported on three collections of $P$. domingensis from Madagascar with apothecia that varied in shape, size and especially in the color of the hymenium (see The Phillipsia domingensis complex in the INTRODUCTION).

Material. BRAZIL. PARANÁ: 7.IV.1991, A. de Meijer (A. de Meijer-1915) (FH, MBM) (DNA); PARANÁ: For. do Iquaçu, Refugio Biologico Bela Vista, 15.X.1992, A. de Meijer (2360) (FH, MBM); PARANÁ: 15.IV.93, A. de Meijer (A. de Meijer-2605) (FH, MBM) (DNA). COSTA RICA. S. of Calaboza, Hato Masaguard, gallery forest, 15.VIII.1980, D. Fragazy (CO1209A) (CSU); HEREDIA: La Selva Biol. Res., 20.I.1986, C. Overbo (CO-1975) (NO) (DNA); ibid., 25.VI.1986, C. Overbo (CO-2032) (NO) (DNA); GUANACASTE: Canton Liberia, Cerro Pedregal, 7.VII.1994, A. E. Franco-M (Franco-M 1270) (NY) (DNA). DOMINICAN REPUBLIC. LA VEGA: Cordillera Central, 12.I.97, O. P. Perdomo (DR-161) (CFMR) (DNA); ibid., 14.I.97, S. A. Cantrell et al (DR-321) (CFMR) (DNA). ECUADOR. NAPO: Añangu, Rio Napo Tropical rain forest, 23.IV.1983, T. Læssøe (T. Læssøe AAU-43662) (AAU, C) (DNA); ibid., 25.VI.1983, T. Læssøe (T. Læssøe AAU-44714) (AAU, C) (DNA); ibid., 29.VI.1983, T. Læssøe (T. Læssøe AAU-44800) (AAU, C) (DNA); ibid., 7.VII.1983, T. Læssøe (T. Læssøe AAU-44913) (AAU, C) (DNA). GUADELOUPE. Saint Claude, Camp Jacob, 7.I.1974, D. H. Pfister et al (1030 \& 1031) (FH); Grand Matouba, 8.I.1974, D. H. Pfister et al (DHP-1116) (FH). PUERTO RICO. Luquillo Mts., El Verde Research Area, 7.IX.90, D. J. Lodge (PR-1579) (CFMR) (DNA); ibid., 12.I.1991, D. J. Lodge (PR-1582) (FH) (DNA); ibid., 16.I.1996, D. H. Pfister et al (DHP PR3) (FH); Luquillo Mts., near Rio Mameyes close to bridge, 17.I.1996, D. H. Pfister et al (DHP PR-40) (FH) (DNA); Palo Colorado Forest, 24.II.1990, D. J. Lodge (PR-1583) (FH) (DNA); near Rio Sabane, Hill above chicken farm, 17.I.1996, D. H. Pfis- 


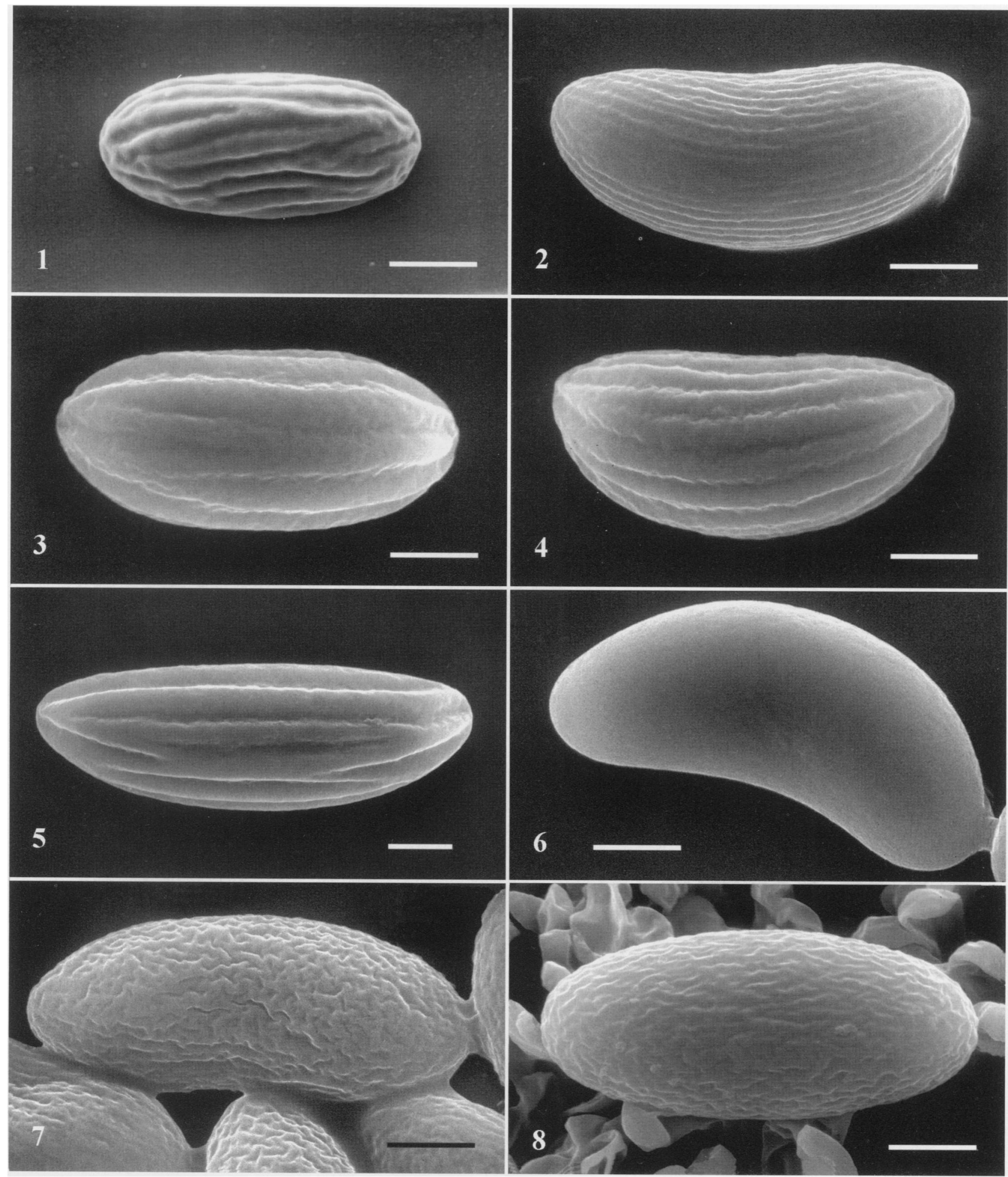

FIGS. 1-8. Ascospore ornamentation as seen by SEM. 1. Phillipsia carnicolor. Low, broad, 6-8 longitudinal irregular, some anastomosing ridges, in profile view (DHP-7126). 2. P. crispata. Very fine, low, 15-18 longitudinal, parallel ridges, in profile view (T. Læssøe AAU-44895a). 3. P. domingensis. Coarse, high, 5-6 longitudinal, parallel ridges, in front view (T. Læssøe AAU44800). 4. $P$. domingensis. 6-7 ridges, in profile view (T. Læssøe AAU-44800). 5. P. lutea. Coarse, high, 5-6 longitudinal, parallel ridges (NY-4113). 6. P. olivacea. Smooth, in profile view (T. Læssøe AAU-44895b). 7. P. olivacea. High wrinkles, in profile view (T. Læssøe AAU-43162). 8. Nanoscypha tetraspora. Low wrinkles, oriented in a somewhat longitudinal way. (PR61). Scale bars $=5 \mu \mathrm{m}$. 
ter and F. A. Harrington (DHP PR39) (FH). USA. FLORIDA: Dade Co., Matheson Hammock, 10.X.1942, R. Singer (F819) (FH); FLORIDA: Gainesville, Newbury Road, 5.X.1974, D. A. Samuelson (DHP-54) (FH); Pearl River, Lousiana, Honey Island swamp, 10.IX.1985, C. Overbo (CO10sept.1985) (NO) (DNA); ST. TAMMANY PARISH, LA: Honey Island swamp, 7.IX.1985, C. Overbo (CO-1864) (NO) (DNA). THAILAND. Kaeng Krachan National ParkTrail to Tor Tip Waterfall, 15.VII.1997, D. H. Pfister (DHP7169) (FH) (DNA).

Phillipsia lutea Denison, Mycologia 61:296. 1969.

Phillipsia lutea is morphologically separated from other species of Phillipsia by its predominantly 4 spored asci and the large, 32.8-33.9-38 × 12.8-14.016 , ellipsoid, inequilateral ascospores with an ornamentation of coarse, high, longitudinal, parallel ridges (easily seen in LM $\times 400$; in SEM with $5-6$, ca 1.3$2.0 \mu \mathrm{m}$ high, ca $1.3-2.0 \mu \mathrm{m}$ broad ridges in profile view, FIG. 5), in combination with the yellow hymenium.

Commentary. The material from French Guiana sequenced in this study was found as a misidentified collection, labeled Phillipsia tetraspora (= Nanoscypha tetraspora) (Courtecuisse et al 1996). The holotype of $P$. lutea morphologically matches the French Guiana collection. Apart from the outer excipulum, which we interpret as dense textura intricata to textura prismatica, with some free hyphal tips protruding on the outer surface, we agree with the description of Denison (1969). Some 6- or 8-spored asci were present and the paraphyses were filled with yellowish refractive granules. No distinctive anatomical features were found, to separate this taxon from other collections examined in the $P$. domingensis complex. In Phillipsia generally there is a tendency for the number of ascospores per ascus to be reduced. The cytology of this phenomenon is unstudied. All ascospores of members of the Sarcoscyphaceae studied to date are multinucleate (Berthet 1964).

Material. COSTA RICA. Alajuela, Pan American Highway near San Ramon, 13.IX.1964, W. C. Denison et al (Denison 2269) (OSC; holotype of $P$. lutea). FRENCH GUIANA. CITRON: Mt. Lucifer, III.1986 [sic] G. J. Samuels \& P. Searwar (NY-4113) (NY) (DNA).

Other yellow Phillipsia's.

Two collections were tentatively called " $P$. yellow" because of their bright yellow hymenium. In other features these collections are identical with $P$. domingensis s.l.

Commentary. The Thailand collection, " $P$. yellow" (2), was collected on the same branch as $P$. domingensis (18), but assumed to be different. However, these collections are most likely produced by the same mycelium (see Parsimony analyses results).

Material. COSTA RICA. HEREDIA: La Selva Biol. Res., 11.VII.1986, M. M. Chavarria (CO-2168) (CFMR) (DNA). THAILAND. Kaeng Krachan National Park-Trail to Tor Tip Waterfall, 15.VII.1997, D. H. Pfister (DHP-7197) (FH) (DNA).

Phillipsia olivacea Rick, Broteria, Res. Bot. 21:134. 1924

$=$ Phillipsia rugospora Paden, Can. J. Bot. 55:2685. 1977.

LECTOTYPE (Designated here). BRAZIL. [RIO GRANDE DO SUL]: Rev. Rick (BPI-Herb. Lloyd 28348). It consists of 11-12 well preserved apothecia. Notes with collection by C. G. Lloyd: "as det. by father Rick. First time I have seen it. I presume it must be a mss. name. The ascospores are elliptical $12 \times$ 32, smooth, two guttulate. Paraphyses filiform, hyaline, furcate above. Context fleshy white. Hyphae slender not inflated." PARATYPE of P. rugospora: J. W. Paden (1092) (UVIC).

Apothecia discoid to shallow cupulate, even in circumference or compressed by mutual pressure, 1-3.5 $\mathrm{cm}$ diam, sessile to very short stipitate $(<2-4 \mathrm{~mm})$, often laterally attached to the substrate; hymenium more or less even, yellow, pale yellow to grayish yellow, dull orange, olive, olive yellow, olive brown, light brown (some colors near 3-4D5-6, 3E-series, 3C4, $4 \mathrm{E} 6,6 \mathrm{D} 7)$; outer surface paler or white, smooth to slightly tomentose, highly wrinkled when dried, due to shrinkage of the thick and very loosely interwoven medullary excipulum. Outer excipulum ca $200 \mu \mathrm{m}$ thick at the base of the apothecia, with an inner layer of dense textura intricata, the hyphae of which, toward the outside of the apothecia, become oriented parallel to the outer surface forming a narrow (rindlike) band of textura prismatica, $40-80 \mu \mathrm{m}$, from which septate hyphal tips up to $6 \times 30 \mu \mathrm{m}$ emerge either singly or in groups forming pustules. Medullary excipulum ca $1800 \mu \mathrm{m}$ thick at the base, of textura intricata, composed of loosely woven hyphae up to 4-7 $\mu \mathrm{m}$ broad. Margin 172-320 $\mu \mathrm{m}$ broad, composed of parallel running hyphae that on the outside give rise to free hyphal tips-sometimes interwoven, terminating at the level of the apices of the asci and paraphyses. Hymenium 360-440 $\mu \mathrm{m}$ high, arising from a subhymenial layer, $60-80 \mu \mathrm{m}$ thick, of densely interwoven hyphae, only slightly differentiated from medullary excipulum. Asci 4-, 6-, or 8-spored, 400$480 \times 14-16 \mu \mathrm{m}$, cylindrical with long tapering bases, an internal eccentric thickened apical pad, J-. Ascospores uniseriate, ellipsoid, slightly to distinctly inequilateral in profile view (reniform), with rounded ends, (24.0-) 26.0-29.0(-32.8) × (10.4-) 12.0-12.2(14.4) $\mu \mathrm{m}$ (83 spores/7 coll.), hyaline, with two large 
guttules (7.2-10.4 $\mu \mathrm{m}$ diam), at maturity thickwalled, $0.8-1.2 \mu \mathrm{m}$, in LM smooth $(\times 1000)$ or slightly wrinkled, in SEM smooth (FIG. 6) or wrinkled (FIG. 7). Paraphyses septate, filiform, anastomosing, at the apex enlarged to $2-3.2 \mu \mathrm{m}$, equal in length to the asci, containing yellowish or olive, refractive granules in the whole length.

Habitat. On dead wood. Often gregarious (5-14 fruitbodies produced at a time).

Distribution. Brazil, Venezuela, Ecuador and Costa Rica.

Material. BRAZIL. [RIO GRANDE DO SUL]: Rev. J. Rick (BPI-Herb. Lloyd 28348) (lectotype of P. olivacea); RIO GRANDE DO SUL, Rev. J. Rick (BPI-Herb. Lloyd 15115); ibid., São Leopoldo, 1929-30, J. Rick (s.n.) (FH); ibid., Serro Azul, 1928, J. Rick (436) (FH); ibid., 1928 (s.n.) (FH); Sta. Catharina, Porto Novo, 1928, J. Rick (s.n.) (FH); ibid., 1928 (s.n.) (FH); Paraná, Curitiba, São José dos Pinhais, ADEA-reserva "Reserva Biologica Cambui," 27.II.1980, A. de Meijer (369b) (MBM). COSTA RICA. Punta Arenas, La Amistad, Fila Palmital, La Amistad Lodge, Sendero Higueron, 19.VI.1995, R. Halling et al (7434) (NY); Punta Arenas, Las Mellizas, Fila Palmital, Sendero Cienaga, 11.VIII.1995, A. E. Franco-M et al (Franco-M 1360) (NY) (DNA); Turrialba, near the Centro Agronomico Tropical de Investigacion y Ensenanza, 12.X.1975, J. W. Paden (1092) (UVIC) (paratype of $P$. rugospora). ECUADOR. NAPO: Añangu, Rio Napo Tropical rain forest, 2.II-15.III.1983, T. Læssøe (T. Læssøe AAU-43162) (AAU, C) (DNA); ibid., 3.V.1983, T. Læssøe (T. Læssøe AAU-43774) (AAU, C) (DNA); ibid., 5.VII.1983, T. Læssøe (T. Læssøe AAU44895b) (AAU, C) (DNA). VENEZUELA. DISTRITO FEDERAL: near Caracas, Parque Nacional "El Avila", 1.VIII.1987, R. E. Halling (Halling-5456) (NY) (DNA).

Commentary. The status of $P$. olivacea is somewhat complicated. The name was used by Rick on various specimens sent to FH and to C. G. Lloyd. Rick (1931) provides a citation for the species: "Litt.: Broteria 1906," which is untraceable. A note by Rick, left with one specimen (no. 436, from 1928, FH), states that he did not publish the name. Yet there is a brief description in a paper in 1924: "Ph. olivacea Rick.-In ligno. Invenitur non raro cum precedente" (i.e., "Phillipsia kermesina Cooke"); "est ejusdem magnitudis, 1-2 cm. lata, sed colore olivaceo differt" (Rick 1924). We consider this to constitute the valid publication by providing a diagnosis. The lectotype has been selected from among the material in Lloyd's herbarium (BPI), since Rick further stated in his note (with the collection no. 436, FH) that, "Phillipsia olivacea Rick is in the Lloyd Museum." All other material of P. olivacea studied by Rick are from 19281930 which dates them after the publication of the description.

The ellipsoid, in profile view slightly to distinctly inequilateral to reniform ascospores, two large gut- tules, and smooth (as nearly always seen by LM) or wrinkled spore wall, are diagnostic features of $P$. olivacea. Likewise, the thin, outermost, often rind-like excipulum of textura prismatica, from which septate hyphal tips emerge, are characteristic. The apothecial colors vary considerably among collections and in the different stages of maturity, ranging from yellow to dull orange, olive or light brown.

One of the paratypes of $P$. rugospora (Paden 1092, UVIC) has been studied (the holotype has not been located and may be lost) and was found to agree both with the Rick material and the more recent collections. Phillipsia rugospora was known to Paden (1977) only from the type locality in Costa Rica. Since then one collection has been reported from Argentina (Romero and Gamundi 1986). Phillipsia rugospora was distinguished by its yellow hymenium, and ascospores with a wrinkled wall when viewed with SEM"the ascospores usually appeared smooth when examined in fresh condition with an oil-immersion objective" (Paden 1977). The spore wall is somewhat peculiar. We observed both wrinkled and smooth ascospores under SEM. Under LM most ascospores appeared to be completely smooth.

Rick (1931) also described the variety $P$. olivacea var. viridis Rick. He described it as "tota viridis." Several collections with this name, made by Rick are in $\mathrm{FH}$. All of these are green due to the more or less uniform coating over the surface of the apothecia of a Penicillium species. We have not examined the type material of this taxon but suspect the concept of this variety to be based on specimens over-run by a mold.

Nanoscypha tetraspora (Seaver) Denison, Mycologia 64:619. 1972.

The outgroup, Nanoscypha, has been characterized by smooth ascospores (in LM) (Denison 1972). Denison (1972) selected Cookeina tetraspora Seaver [= Phillipsia tetraspora (Seaver) Le Gal], as the type species for Nanoscypha when he described the genus. In the original description of C. tetraspora, Seaver (1925) reported the ascospores as often showing faint striations, depending on the maturity of the ascospores. In addition, Le Gal (1953) seemed uncertain about whether the ascospores were smooth or striate. In the Puerto Rico material studied here the wall of $N$. tetraspora ascospores were found to be wrinkled, in a somewhat longitudinal way, in SEM (FIG. 8). In LM the ascospores were seen as smooth. One of us (DHP) has observed (in LM) the striations noted by Seaver in his collections from Puerto Rico. It may be that in certain mature ascospores the wrinkles seen in SEM become more prominent. 

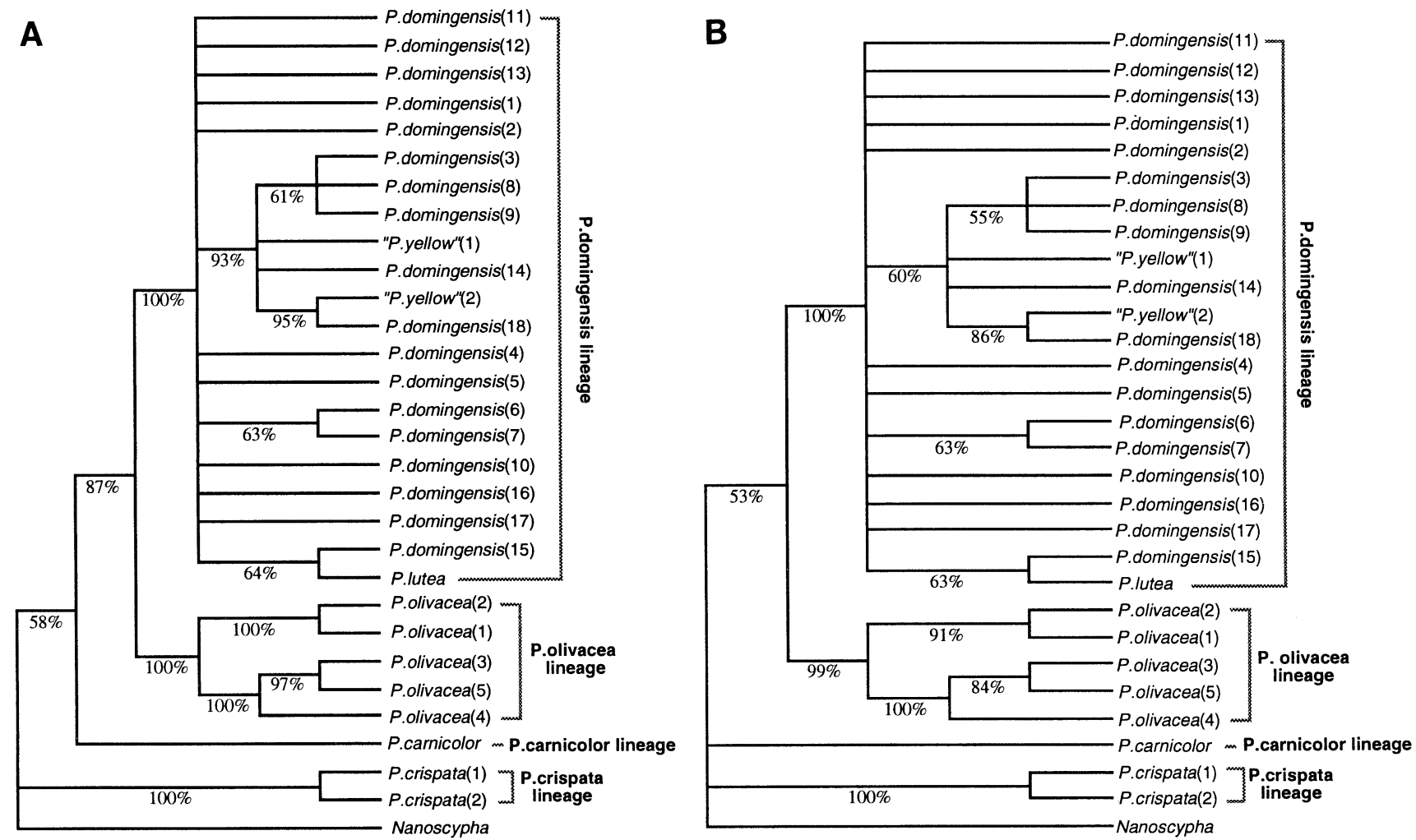

FIG. 9. A. Unrooted strict consensus of 15000 equally parsimonious trees (264 steps) generated under gap $=$ missing coding. B. Unrooted strict consensus of 8 equally parsimonious trees (181 steps) generated with gapped positions omitted. Bracketed groups correspond to the 4 lineages recognized. Numbers below branches are frequency of occurence in 1000 bootstrap replicates (values $<50 \%$ not shown).

Material. PUERTO RICO. El Yungue National Park, 18.I.1996, D. H. Pfister et al (DHP PR-61) (FH) (DNA).

Molecular phylogenetic analysis.-Alignment. All positions were alignable across the Phillipsia sequences, except for one region in ITS1. This region was only unambiguously alignable within the morphological species [grouping $P$. lutea and " $P$. yellow" (1), (2) with $P$. domingensis s.l.], except for the one sequence of $P$. carnicolor which was alignable with the $P$. olivacea sequences. This region consisted of $32 \mathrm{bp}$ in the P. domingensis complex, $39 \mathrm{bp}$ in P. crispata and 38 bp in $P$. olivacea/P. carnicolor. The Nanoscypha sequence could not be aligned to any of these hypervariable regions. These positions were offset in blocks, spaced out with gaps, adding approximately $100 \mathrm{bp}$ to the alignment. One additional region in Nanoscypha (position 246-269) did not align to the ingroup. The aligned length of all sequences including inserted gaps was $768 \mathrm{bp}$. The approximate length of ITS1 (gaps excluded) was $178 \mathrm{bp}$ in Phillipsia and $152 \mathrm{bp}$ in Nanoscypha. ITS2 was $180 \mathrm{bp}$ in both genera. The $5.8 \mathrm{~S}(157 \mathrm{bp})$ was almost identical across all collections, except for nucleotide substitutions in seven positions, in the region $40 \mathrm{bp}$ before the start of ITS2. The flanking partial sequences of $18 \mathrm{~S}$ (ca. $64 \mathrm{bp})$ and $25 \mathrm{~S}(60 \mathrm{bp})$ rDNA were likewise conserved.

Parsimony analyses. Under gap $=$ missing coding, there were 128 informative characters. With gapped positions omitted this number decreased to 86 . When gaps were coded as missing parsimony analyses yielded over 15000 equally parsimonious trees, of 264 steps [consistency index CI $=0.809$, retention index $\mathrm{RI}=0.916]$, whereas analyses with gapped positions omitted yielded only 8 trees, of 181 steps $(\mathrm{CI}=0.845$, $\mathrm{RI}=0.892)$. The large number of equally parsimonious trees under gaps $=$ missing coding reflect the poor resolution within the $P$. domingensis complex. However, only a few branches in one of 15000 equally parsimonious trees collapse in the strict consensus tree (all branches within the $P$. domingensis complex). With gapped positions omitted most of these branches collapse in the analyses (creating polytomies), as the branch length is reduced to zero and therefore the number of equally parsimonious trees are strongly reduced (from over 15000 trees to 8 trees). Despite the large difference in the number of equally parsimonious trees produced, there is no pos- 
itive conflict between the strict consensus trees of the two sets of analyses (FIGs. 9A, B). However, the basal node of the ingroup topology is unresolved in the strict consensus of the trees produced with gapped positions omitted, with $P$. crispata, and the $P$. domingensis complex and $P$. olivacea, and $P$. carnicolor forming a trichotomy (FIG. 9B). Half of the 8 equally parsimonious trees had the ingroup root placed along the branch leading to the $P$. crispata lineage (FIG. 10). This topology is identical with the topology in the strict consensus tree derived from the analysis with gaps $=$ missing (FIG. 9A). The other half of the trees had the ingroup root placed along the branch leading to the $P$. domingensis and $P$. olivacea lineage (FIG. 10), grouping the P. carnicolor lineage with the $P$. crispata lineage.

Phylogenetic analysis under gaps $=$ missing coding identified three well-supported lineages of rDNA, as measured by bootstrapping: the $P$. crispata lineage (bootstrap 100\%), the P. olivacea lineage (bootstrap $100 \%)$ and the $P$. domingensis lineage (bootstrap $100 \%$ ) (FIG. 9A). The P. crispata lineage, consisting of two collections of $P$. crispata from Ecuador, is separated by 49 steps from the root of the tree (FIG. 10, number of steps under gaps $=$ missing coding are indicated in parentheses above branches). The $P$. domingensis and $P$. olivacea lineages form a clade (bootstrap 87\%) (FIG. 9A). The branch uniting these two lineages is 26 steps. The branches leading to the $P$. domingensis and $P$. olivacea lineages are each 19 and 16 steps. The $P$. domingensis lineage includes 18 collections of $P$. domingensis s.l., " $P$. yellow" (1), (2), and the single collection of $P$. lutea. In general, there was very little resolution in this group. Nevertheless, one clade (FIG. 9A), consisting of five collections of $P$. domingensis s.l. and "P. yellow" (1), (2) (collections from Costa Rica, Dominican Republic, USA and Thailand), is strongly supported (bootstrap 93\%). Within this clade (FIG. 9A) the two Thailand collections are strongly supported (bootstrap 95\%, these collections are possibly from the same mycelium, since they were collected on the same branch, but were apothecia of highly divergent hymenial colors, bright yellow ["P. yellow" (2)] and pinkish $[P$. domingensis (18) ]. The $P$. olivacea lineage is composed of two well-supported clades (bootstrap 100\%), containing collections from Ecuador, Venezuela and Costa Rica (FIG. 9A). The one collection of $P$. carnicolor from Thailand constitutes a separate lineage, and is the sister group to the $P$. domingensis- $P$. olivacea clade. The branch leading to the $P$. carnicolor lineage is 23 steps.

Parsimony analysis with gapped positions omitted revealed similar levels of bootstrap support for the three main lineages (FIGs. 9B, 10). Bootstrap values for the clades within the $P$. domingensis lineage however, were all lower. The monophyly of the $P$. domingensis and $P$. olivacea lineage was only weakly supported (bootstrap 53\%). The branch uniting the $P$. carnicolor lineage and the $P$. crispata lineage in four of the eight trees is 10 steps, with the branches of the $P$. carnicolor and $P$. crispata lineages each 20 and 44 steps (topology not shown).

\section{DISCUSSION}

The four distinct rDNA lineages found in the phylogenetic analysis correspond to morphologically similar groups: $P$. crispata, the $P$. domingensis complex, $P$. olivacea and $P$. carnicolor (FIG. 10). The first three lineages are all well supported as monophyletic by $99-100 \%$ of the bootstrap replicates, but the $P$. carnicolor lineage is represented by only one collection. Although the $P$. domingensis lineage and $P$. olivacea lineage form a clade, the monophyly of this clade is not strongly supported when gapped positions are omitted (bootstrap values decrease from $87 \%$ to $53 \%$ ).

The position of the $P$. carnicolor lineage is uncertain. Phillipsia carnicolor forms either a separate lineage as sister group to the $P$. domingensis-olivacea lineage (FIG. 10) or a monophyletic group with the $P$. crispata lineage (when gapped positions are omitted, Fig. 10; arrowed). The P. crispata lineage (with or without the $P$. carnicolor lineage) is the sister group to the $P$. domingensis $-P$. olivacea clade. Moravec (1997) suggested that $P$. carnicolor belongs to an infrageneric taxonomic group, characterized by "small stipitate apothecia with an orange, pale red to pink hymenium and a thin medullary excipulum of a firm consistency," along with P. crenulata Berk. \& Broome. Already, Rifai (1968) recognized a group of species within this "series," characterized further by short asci, with broad untapering bases. To this group he allocated P. umbilicata (Penz. \& Sacc.) Boedijn. Phillipsia carnicolor is characterized by this type of ascus. To confirm the monophyly of the $P$. carnicolor group hypothesis, sampling of more taxa within this group is necessary. In no case, however, do the Phillipsia species in our analyses form a monophyletic group excluding $P$. carnicolor. Our results suggest that $P$. carnicolor is in the main Phillipsia lineage, which does not support the division of Phillipsia into several genera, as tentatively suggested by Moravec (1997).

The four main lineages inferred from the ITS topologies are all supported by spore morphology (FIG. 10). (i) P. domingensis s.l., P. lutea and "P. yellow" are united by the spore shape and ornamentation: ellipsoid, inequilateral ascospores, with an ornamentation of 3-7 coarse, longitudinal ridges in profile view 


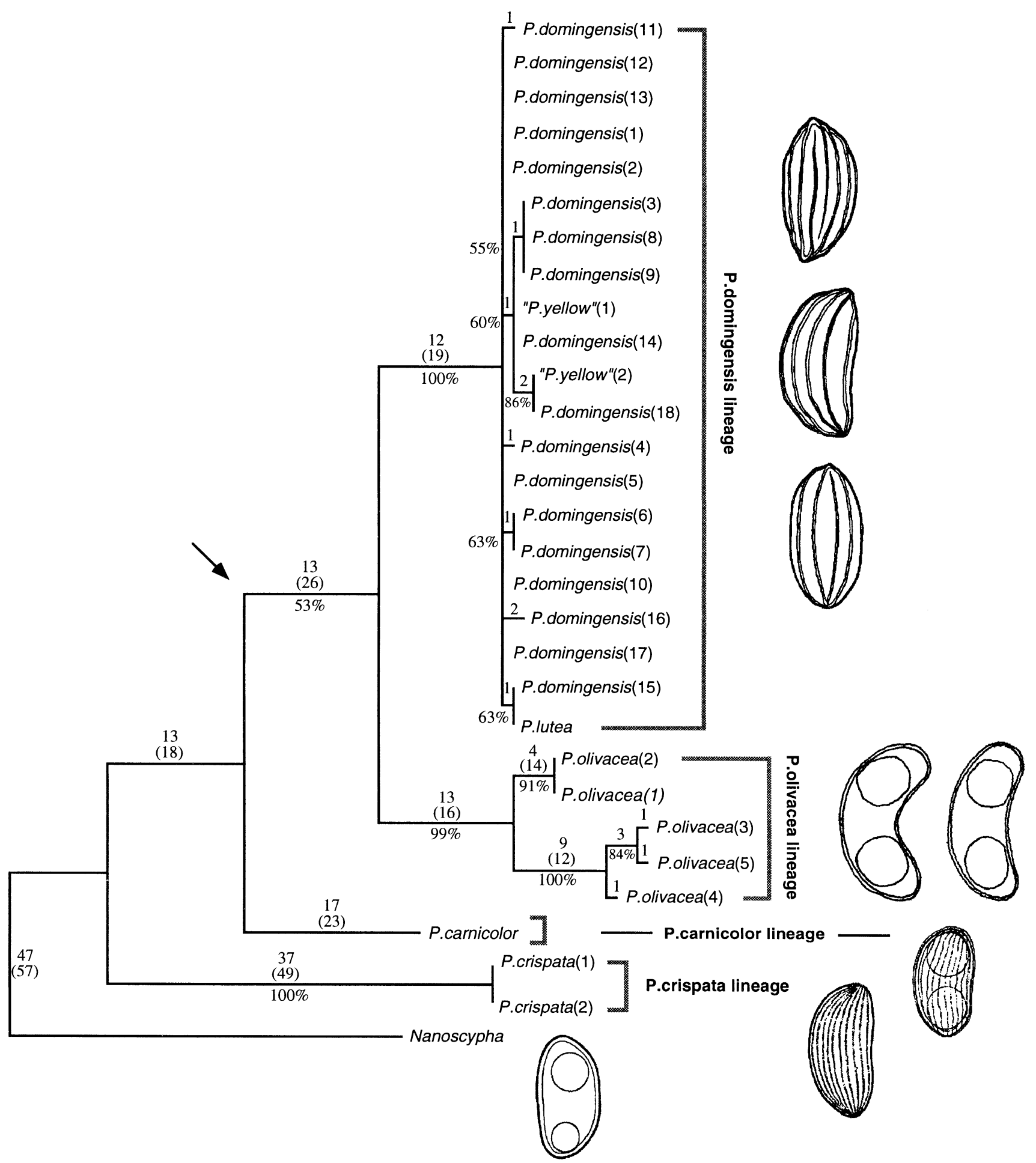

FIG. 10. Phylogram depicting one of 8 equally parsimonious trees (181 steps) for ITS sequences, generated with gapped positions omitted. Terminal taxa are individual collections (see TABLE I). Bootstrap values from 1000 replicates are given below branches (values $<50 \%$ not shown). Branch lengths are proportional to the number of steps (character changes) along the branch (given above each branch). The main topology of one of 15000 equally parsimonious trees (264 steps) generated under gaps $=$ missing coding are identical, and the branch lengths from this coding scheme are indicated in parentheses above each branch. Arrow indicate alternative rooting option with gapped positions omitted. Spore morphology supporting each recognized lineage and the outgroup are shown (for Nanoscypha and P. olivacea only smooth ascospores are shown), ca scale $\times 1.000$ (reproduced from Le Gal 1953). 
(FIGs. 3-5). (ii) The P. olivacea lineage has ascospores with a smooth (FIG. 6) or wrinkled spore wall (FIG. 7). (iii) The $P$. crispata lineage has ascospores with an ornamentation of 10-15 very fine, longitudinal, parallel ridges in profile view (FIG. 2). (iv) The $P$. carnicolor lineage has ascospores with an ornamentation of 6-8 low, broad, longitudinal irregular, parallel, some anastomosing ridges (FIG. 1). The outgroup, Nanoscypha, has ascospores with smooth or wrinkled spore walls (FIG. 8). Assuming that the rDNA phylogeny is congruent with the species/population phylogeny we suggest that the four rDNA lineages revealed here could be recognized as phylogenetic species.

To further understand relationships within Phillipsia, it would be valuable to perform analyses that include species with different numbers of ridges in their spore ornamentation, such as $P$. costaricensis, which has spores with 7-9 distinct ridges. More taxa with seemingly smooth ascospores would likewise be important to investigate.

Color has been emphasized in taxonomy of Phillipsia (e.g., Denison 1969, Ito and Imai 1937, Le Gal 1953, Moravec 1997). Nevertheless, these results indicate that individuals with strikingly different coloration may be closely related. The bright yellow forms ( $P$. lutea and " $P$. yellow") are nested within the $P$. domingensis complex and are not monophyletic, which suggest that yellow apothecia have been derived from reddish apothecia at least twice. This suggests that derivation of yellow from reddish apothecia may involve a simple genetic change. Pigments in three "species" of Phillipsia ( $P$. carminea, P. subpurpurea and $P$. carnicolor) have been studied (Arpin 1969). A carotenoid pigment, phillipsiaxanthin, exists in two forms (as di- and mono-esters) in the species studied. Whether this pigment can undergo changes that give the hymenium variable colors under different environmental conditions has not been demonstrated, but Griffin (1994) notes that the color of carotenoids depends on the degree of saturation of the carbon backbone. Color should be used with caution as a taxonomic character, until further work has been undertaken on the stability of these carotenoids, and should not be used alone to distinguish Phillipsia species. In closely related genera, Sarcoscypha (Fr.) Boudier and Cookeina Kuntze, hymenial colors likewise vary considerably. Cookeina speciosa (Fr. : Fr.) Dennis has been treated as including a range of color forms [Denison 1967; as C. sulcipes (Berk.) Kuntze]. A bright orange form of the normally scarlet red cup, Sarcoscypha austriaca (Sacc.) Boud. has been observed in Denmark (Lange 1998).

ITS provided very little resolution in the $P$. domingensis lineage. A single clade of five collections of
$P$. domingensis and both collections of " $P$. yellow" was well supported, but so far we have not been able to find any consistent morphological characters that distinguish this clade from the rest of the $P$. domingensis lineage. The Old World collection(s) of the $P$. domingensis complex $[P$. domingensis (18) and " $P$. yellow" (2)] were nested within the New World collections, indicating that the $P$. domingensis lineage is geographically widespread. Based on this study there is no justification for recognizing segregate species within the $P$. domingensis complex. Ascospore germination in $P$. domingensis and $P$. lutea are shown to differ (Paden 1974) and different anamorphs, Molliardiomyces domingensis Paden and M. luteus Paden, are described for each of these "morphologically defined species" (Paden 1984). The ascospores of $P$. domingensis developed one septum and produced, mostly two, germ tubes with conidialike structures, while ascospores of $P$. lutea germinated with a single germ tube, which did not form conidialike structures. We observed ascospores of " $P$. yellow" (1) germinating in the asci and on the hymenial surface in the same manner as described for $P$. domingensis. However, further germination experiments and studies of the anamorphic states are needed to critically evaluate the taxonomic use of these characters. The two types of germination are similar to those found in Sarcoscypha (Baral 1984, Harrington 1990, Butterfill and Spooner 1995). The name Sarcoscypha coccinea (Jacq. : Fr.) Lambotte has been used for a complex of species (Baral 1984), which are macroscopically remarkably similar. Five taxa were recognized within this complex, with ascospore germination and production of conidia as key morphological characters (along with excipular hairs, shape of the apices of the ascospores and ascospore guttulation). However, within Sarcoscypha analysis based on ITS data did resolve monophyletic groups that corresponded to the morphologically defined species (Harrington and Potter 1997). To understand relationships within the $P$. domingensis lineage, more rapidly evolving sequences may be useful, such as the intergenic nontranscribed spacers of rDNA (Anderson and Stasovski 1992). In addition, a more comprehensive study of Phillipsia must include more sampling from Asia, as well as sampling from Australasia and Africa.

\section{ACKNOWLEDGMENTS}

We thank Thomas Læssøe, Sharon A. Cantrell, Jean Lodge, Roy Halling, Clark Overbo, A. de Meijer for providing specimens, Mimi Harrington for sharing unpublished data, the curators of BPI, C, CFMR, CSU, MBM, NO, NY, OSC and UVIC who kindly arranged the loan of material, Thomas Læssøe (Copenhagen) for making various helpful sugges- 
tions on the manuscript, Nancy Weber for careful review of the paper, and the "Muséum National d'Histoire Naturelle: Laboratoire de Cryptogamie" for permission to reproduce the spore illustrations in Fig. 10, by Marcelle Le Gal, from Les Discomycétes de Madagascar, 1953. This research was supported by an NSF grant (DEB-9521944) to Donald H. Pfister and Michael J. Donoghue. Danmark Amerika Fondet (the Danish American Foundation) supported the stay of $\mathrm{KH}$ in the USA.

\section{LITERATURE CITED}

Anderson JB, Stasovski E. 1992. Molecular phylogeny of northern hemisphere species of Armillaria. Mycologia 84:505-516.

Arpin N. 1969. Les caroténoïdes des Discomycètes: essai chimiotaxinomique. Bull Mens Soc Linn Lyon 38(suppl.): $1-169$

Baral HO. 1984. Taxonomische und ökologische studien über Sarcoscypha coccinea agg., zinnoberrote kelchbecherlinge. (Kurzfassung). Z Mykol 50:117-145.

Berkeley MJ. 1881. Australian fungi-II. J Linn Soc Bot 18: 383-389.

Berthet P. 1964. Essai Biotaxinomique sur les Discomycètes. Lyon: Joanny Lorge. 157 p.

Boedijn KB. 1933. The genera Phillipsia and Cookeina in Netherlands India. Bull Jard Bot Buitenzorg 13:57-76.

- 1940. The mycetozoa, fungi and lichenes of the Krakatau group. Bull Jard Bot Buitenzorg 16:358-429.

Butterfill GB, Spooner BM. 1995. Sarcoscypha (Pezizales) in Britain. Mycologist 9:20-26.

Courtecuisse R, Samuels GJ, Hoff M, Rossman AY, Cremers G, Huhndorf SM, Stephenson SL. 1996. Check-list of fungi from French Guiana. Mycotaxon 57:1-85.

Denison WC. 1967. Central American Pezizales. II. The genus Cookeina. Mycologia 59:306-317.

- 1969. Central American Pezizales. III. The genus Phillipsia. Mycologia 61:389-304.

- 1972. Central American Pezizales. IV. The genera Sarcoscypha, Pithya and Nanoscypha. Mycologia 64:609623.

Felsenstein J. 1985. Confidence limits on phylogenies: an approach using the bootstrap. Evolution 39:783-791.

Georgiev OI, Nikolaev N, Hadjiolov AA. 1981. The structure of the yeast ribosomal RNA genes. 4. Complete sequence of the $25 \mathrm{~S}$ rRNA gene from Saccharomyces cerevisiae. Nucl. Acids Res. 9:6953-6958.

Griffin DH. 1994. Fungal physiology. 2nd ed. New York: Wiley-Liss, Inc. 458 p.

Harrington FA. 1990. Sarcoscypha in North America (Pezizales, Sarcoscyphaceae). Mycotaxon 38:417-458.

— genetic studies within the Pezizales. I. 18S rRNA sequence data and classification. Mycologia 91:41-50.

Sarcoscypha based upon nucleotide sequences of the internal transcribed spacer of nuclear ribosomal DNA. Mycologia 89:258-267.

Hibbett DS, Fukumasa-Nakai Y, Tsuneda S, Donoghue MJ.
1995. Phylogenetic diversity in shiitake inferred from nuclear ribosomal DNA sequences. Mycologia 87:618638.

Holmgren PK, Holmgren N, Barnett L. 1990. Index herbariorum. New York: NY Bot. Garden. 693 p.

Ito S, Imai S. 1937. Fungi of the Bonin Islands. II. Trans. Sapporo Nat. Hist. Soc. 15:52-59.

Korf RP. 1973. Discomycetes and Tuberales. In: Ainsworth GC, Sparrow FK, Sussmann AS, eds. The fungi, an advanced treatise IV. New York: Academic Press. p 249319.

Kornerup A, Wanscher JH. 1974. Farver i farver. 5th print. København: Politikens Forlag. 248 p.

Lange C. 1998. En fejlfarvet Pragtbæger. Svampe 38:9-11.

Le Gal M. 1953. Le Discomycètes de Madagascar. Prodr Flore Mycol Madagascar 4:1-465.

- 1959. Discomycètes du Congo Belge d'après les récoltes de Madame Goossens-Fontana. Bull Jard Bot État. 29:73-123.

Li L-T, Kimbrough JW. 1996. Spore ontogeny in species of Phillipsia and Wynnea (Pezizales). Can J Bot 74:10-18.

Maddison DR. 1991. The discovery and importance of multiple islands of most-parsimonious trees. Syst Zool 40: 315-328.

—, Ruvolo M, Swofford DL. 1992. Geographic origins of human mitochondrial DNA: phylogenetic evidence from control region sequences. Syst Biol 41:111-124.

Massee G. 1896. Redescriptions of Berkeley's types of fungi. J Linn Soc Bot 31:462-526.

Moravec J. 1997. Discomycetes of Madagascar-I. Phillipsia ranomafanensis sp. nov. and ascospore sculpture of Cookeina colensoi proved by SEM (Discomycetes, Pezizales, Sarcoscyphaceae). Czech Mycol 50:21-33.

Olmstead RG, Bremer B, Scott KM, Palmer JD. 1993. A molecular systematic analysis of the Asteridae sensu lato based on $r b c \mathrm{~L}$ sequences. Ann Missouri Bot Gard 80: $700-722$.

Paden JW. 1974. Ascospore germination in Phillipsia domingensis and P. lutea. Mycologia 66:25-31.

1977. Two new species of Phillipsia from Central America. Can J Bot 55:2685-2692.

- 1984. A new genus of Hyphomycetes with teleomorphs in the Sarcoscyphaceae (Pezizales, Sarcoscyphineae). Can J Bot 62:211-218.

Rick J. 1924. Fungi gelatinosi et cartilaginosi Rio-Grandenses. Broteria Res Bot 21:134.

- 1931. Monographia Pezizinearum Riograndensium. Brotéria-série botânica 25:77-98.

Rifai MA. 1968. The Australian Pezizales in the herbarium of the Royal Botanical Gardens of Kew. Verh Kon Ned Akad Wetensch, Afd Natuurk, Tweede Sect 57:1-295.

Romero AI, Gamundi IJ. 1986. Algunos discomycetes xilofilos del area subtropical de la Argentina. Darwiniana 27:43-63.

Rubstov PM, Musakhanov MM, Zakharyev VM, Krayev AS, Skryabin KG, Bayev AA. 1980. The structure of the yeast ribosomal RNA genes. I. The complete nucleotide sequence of $18 \mathrm{~S}$ ribosomal RNA gene from Saccharomyces cerevisiae. Nucl Acids Res 8:5779-5794. 
Seaver FJ. 1925. Studies in tropical Ascomycetes-III. Porto Rican cup-fungi. Mycologia 17:45-50.

. 1927. A tentative scheme for the treatment of the genera of the Pezizaceae. Mycologia 19:86-89.

1928. The North American cup-fungi (operculates). New York: Hafner Publishing Co., Inc. 428 p.

Swofford DL. 1993. PAUP. Phylogenetic analysis using parsimony, version 3.1. Champaign: Illinois Natural History Survey.

Thweatt R, Lee JC. 1990. Yeast precursor ribosomal RNA: molecular cloning and probing the higher-order struc- ture of the internal transcribed spacer I by kethoxal and dimethylsulfate modification. J Mol Biol 211:305320.

White TJ, Bruns TD, Lee S, Taylor JW. 1990. Amplification and direct sequencing of fungal ribosomal RNA genes for phylogenetics. In: Innis MA, Gelfand DH, Sninsky JJ, White T, eds. PCR protocols. San Diego California: Academic Press. p 315-322.

Yeh LC, Lee JC. 1990. Structural analysis of the internal transcribed spacer 2 of the precursor ribosomal RNA from Saccharomyces cerevisiae. J Mol Biol 211:699-712. 